\title{
Deleterious BRCA2 Gene Mutation
}

National Cancer Institute

\section{Source}

National Cancer Institute. Deleterious BRCA2 Gene Mutation. NCI Thesaurus. Code

C128815.

A change in the nucleotide sequence of the BRCA2 gene that is associated with increased risk of disease. 